\title{
Intelligent Optimization of Wire-EDM parameters for Surface Roughness and Material Removal Rate while Machining WC-Co Composite
}

\author{
Kapil Gupta \\ Associate Professor \\ Mechanical and Industrial Engineering \\ Technology, University of Johannesburg \\ Doornfontein Campus, Johannesburg \\ South Africa
}

This work presents the wire-EDM of WC-Co composite and optimization of process parameters using an integrated technique of response surface methodology (RSM), Vise Kriterijumska Optimizacija Kompromisno Resenje (VIKOR) and artificial bee colony $(A B C)$ algorithm to obtain the best set of machinability indicators. Wire feed (WF), servo voltage (SV), pulse off-time (Pon) and pulse on-time (Poff) are the variable process parameters, whereas root mean square roughness $(R q)$, average surface roughness $(\mathrm{R} a)$ and material removal rate $(M R R)$ are the machinability indicators considered in the present work. A total of twenty nine experiments have been conducted based on Box Behnken design (BBD) technique of response surface methodology. VIKOR has been used for normalization of responses and followed by solving empirical models using $A B C$ algorithm to obtain optimized process parameters setting. WF- 12 $\mathrm{m} / \mathrm{min}, \mathrm{SV}-65 \mathrm{~V}$, Pon- $116 \mu \mathrm{s}$, Poff- $20 \mu \mathrm{s}$ are the optimum wire-EDM parameters obtained by intelligent RSM-VIKOR-ABC technique that produced best values of $R a-4.51 \mu \mathrm{m}, \mathrm{Rq}-5.64 \mu \mathrm{m}, \mathrm{MRR}-0.061 \mathrm{~mm} / \mathrm{min}$ simultaneously. The validation test confirmed an improvement up to $15 \%$ in the response characteristics which proved the effectiveness of this novel hybrid technique for optimization. The optimum parameter setting is for ready industrial reference to attain best surface quality and process productivity for WC-Co composite machining by wire-EDM.

Keywords: Composite; optimization; surface roughness; VIKOR; WireEDM.

\section{INTRODUCTION}

Cemented tungsten carbide (WC) is one of the most successful composites developed by powder metallurgy using $\mathrm{Ni}$ or $\mathrm{Co}$ as binder at a temperature nearly equal to melting temperature $[1,2]$. The ductile material like cobalt ameliorates the toughness value by which brittle fracture can be prevented. Due to unique characteristic of corrosion resistance and high hardness, the applications of material are found in tools, dies and other special equipment [3]. The WC-Co composites exhibit characteristics such as high melting temperature, high hardness and high strength, and therefore categorized as difficult to machine (DTM) material. Thus, the capability of machining processes is of great importance to make products by these composites. Conventional machining processes turn-out to be expensive and environmentally unfriendly due to high tool wear, long machining time, high consumption of coolant, and excessive requirement of post finishing operations [4-7]. It has compelled to explore new ways to attempt machining of such DTM materials. One of such ways is to use advanced machining processes. Wire electric discharge

Received: April 2021, Accepted: May 2021

Correspondence to: Prof. Kapil Gupta, Mechanical and Industrial Eng.Technology, University of Johannesburg, Doornfontein Campus, Johannesburg, South Africa

E-mail:kgupta@uj.ac.za

doi:10.5937/fme2103756G

(C) Faculty of Mechanical Engineering, Belgrade. All rights reserved machining (wire-EDM or WEDM) is a variant of electric discharge machining (EDM) machining process and works on the material removal principle of thermoelectric erosion [8, 9]. In WEDM, a travelling wire (brass, copper or molybdenum) is used as an electrode. It has an ability to produce intricate profiles on hard and conductive materials with an excellent accuracy keeping a constant distance (i.e. without making mechanical contact) in between the workpiece and electrode [8].

A review of past work has been conducted on EDM or WEDM of WC composites [10-14]. Optimization of machining process parameters is also an essential and challenging task to obtain the best possible machinability, specially when machine DTM materials using advanced machining processes [15-17]. As regards to that review of some past literature on optimization of EDM and wire-EDM parameters for DTM materials, using hybrid intelligent techniques, has been done [18-22].

Lee and $\mathrm{Li}$ [10] machined $\mathrm{WC}$ by EDM and investigated that the main parameters affecting the surface quality are pulse duration and peak current. Poor surface quality is obtained at high value of peak current and pulse duration the surface integrity along with the surface features of the machined. Naveed et al. [11] successfully fabricated various typical curved profiles on WC-Co composite using WEDM. They found pulseon time, servo voltage, and wire tension as the most significant factors affecting the radii of the profiles. The 
work of Mahdavinejad [12] was based on the reason analysis for the instability during the machining of WC composite by EDM. After the analysis, it was observed that the arcing pulses, short circuit and open circuit play a crucial role in the instability of machining. It was found that the pulse duration is directly proportional to machine tool instability. Increase in the pulse duration, enhance the instability due to more material removal from the surface of material, makes machined surface rough. The electrical conductivity of the material by the addition of cobalt severely affects the performance characteristics in machine tool. High amount cobalt percentage in material worsen the surface finish due to significant deposition on material. The high electrical conductivity of dielectric acts as a catalyst and deteriorates the surface quality [13]. The research completed by Lauwers et al. [14] emphasized on the analysis of the effect of grain size and cobalt percentage on the responses during WEDM. It was predicted that the change in binder percentage and its grain size varies the thermal conductivity of the material, which becomes the main reason for low cutting speed during the WEDM process.

Several attempts have been made by researchers to find out the optimal condition by employing a wide range of statistical and/or soft computing type hybrid optimization techniques during machining of a wide range of DTM materials by EDM and WEDM. An important work reported by Majumder and Maity [18] highlighted the effectiveness of MOORA-Fuzzy hybrid technique for WEDM parameter optimization to obtain better surface roughness (average roughness $\mathrm{Ra}$, root mean square roughness $\mathrm{Rq}$, and maximum roughness $\mathrm{Rz}$ ) and work microhardness during machining of nitinol shape memory alloy. A significant improvement upto $66 \%$ was achieved in reducing roughness on the nitinol part. A hybrid method including a back-propagation neural network (BPNN), a genetic algorithm (GA), and response surface methodology (RSM) was found effective for optimization of WEDM parameters when cut tungsten material [19]. The optimal parameter setting yielded $0.2704 \mathrm{~g} / \mathrm{min}$ MRR and $1.3561 \mu \mathrm{m}$ Ra. Mukherjee et al. [20] used six different optimization algorithms for WEDM parameter optimization to obtain higher material removal rate, lower wire wear, and better surface finish. They found biogeography-based optimization technique as the most superior for single as well as multiperformance optimization. A hybrid analytical hierarchy and TOPSIS approach was successfully used to solve the multi-criteria decision making problem in electric discharge machining of tungsten carbide (WC-Co) using graphite electrode [21]. The optimum values of responses were $4.0125 \mathrm{~mm}^{3} / \mathrm{min}$ MRR, $0.00012 \mathrm{gm} / \mathrm{min}$ tool wear rate, and $2.28 \mu \mathrm{m}$ surface roughness. El-Bahloul [22] conducted research work on optimization of wire-EDM parameters using statistical method integrated with Fuzzy and successfully improved WEDM productivity and surface quality of 304 stainless steel.

Literature review summarizes that hybrid optimization techniques have been effectively used for successful optimization of EDM and WEDM processes; however, there exists a dearth of research on the optimi- zation of WEDM parameters using hybrid intelligent approaches to secure the best machinability of WC-Co type material. The present research attempts to fulfil this gap where $\mathrm{WC}-5.4 \% \mathrm{Co}$ composite is machined by WEDM and further process parameters are optimized using an intelligent approach based on hybridization of response surface methodology (RSM), Vise Kriterijumska Optimizacija Kompromisno Resenje (VIKOR) and artificial bee colony (ABC) algorithm.

\section{EXPERIMENTAL DETAILS}

WC-Co composite was used in the present research with a $5.4 \%$ of cobalt. The energy dispersive $\mathrm{x}$-ray analysis (EDXA) of this material is shown in Fig. 1. The dimensions of work-material are $200 \mathrm{~mm} \times 8 \mathrm{~mm} \times 8 \mathrm{~mm}$ and the specimen size is $15 \mathrm{~mm} \times 5 \mathrm{~mm} \times 8 \mathrm{~mm}$. EDXA was done to confirm the chemical composition of material. WCCo has widespread applications as a die and tool material. The density and hardness of material are 14.95 $\mathrm{g} / \mathrm{cm}^{3}$ and 77 HRC respectively.

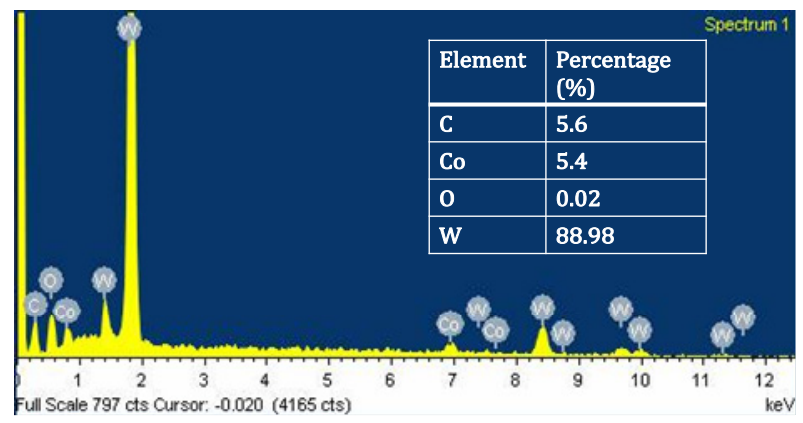

Figure 1. EDXA showing composition of WC-Co composite

Five-axis Ecocut (ELPLUS-15) CNC WEDM is used for the experimentation purpose. In this work, four WEDM process parameters such as wire feed $(3-12 \mathrm{~m}$ $/ \mathrm{min})$, servo voltage $(35-65 \mathrm{~V})$, pulse off-time $(20-40 \mu \mathrm{s})$ and pulse on-time $(108-116 \mu \mathrm{s})$ have been varied at three levels each. The working range as described above is evaluated after performing preliminary experiments. The zinc coated brass wire (diameter $0.25 \mathrm{~mm}$ ) was used for the machining of WC-Co composite to sustain high discharge energy. Fig. 2 depicts the sequence of tasks performed in the present work. The experiments were planned according to Box Behnken design (BBD) design of experiments technique of response surface methodology [23]. The experimental design matrix is depicted in Table 1. A total of 29 experiments were conducted. Material removal rate (MRR), average surface roughness $(\mathrm{Ra})$ and root mean square deviation $(\mathrm{Rq})$ are the response characteristics investigated as machinability indicators in the present research.

In this work, the MRR (higher the better type), and $\mathrm{Ra}$ and $\mathrm{Rq}$ (smaller the better type) characteristics make it a multi-objective problem. The metal removal rate is evaluated using formula (1):

$$
\mathrm{MRR}=\mathrm{CR} * \text { Kerf width*height }
$$

The cutting rate (CR) during machining was recorded from the WEDM machine tool display. The surface roughness was measured across the wire travel using Mitutoyo make surface roughness tester SJ-301P. 


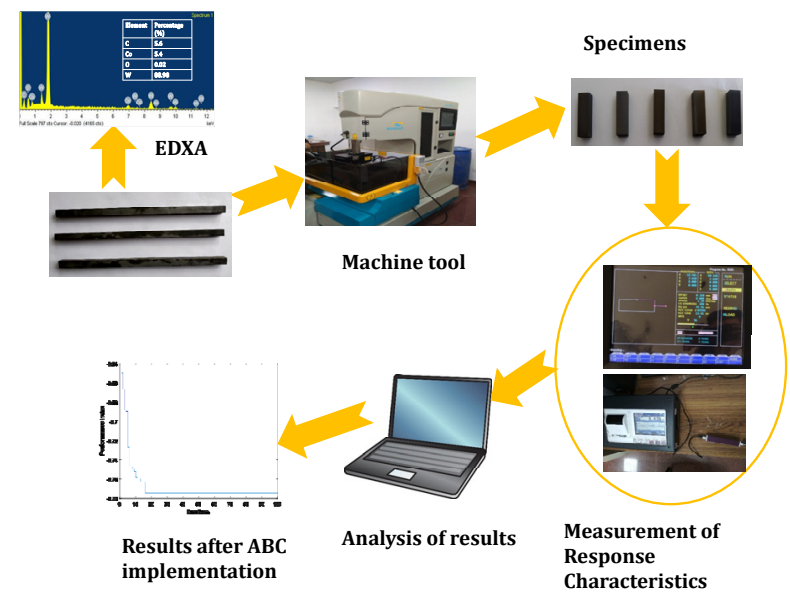

Figure 2. Sequence of tasks performed in the present work

\section{RESULTS AND DISCUSSION}

The experimental results at every parameter com-bination for all 29 runs are shown in Table 1 . The methodology adopted for optimization in the present work is shown in Fig. 3.

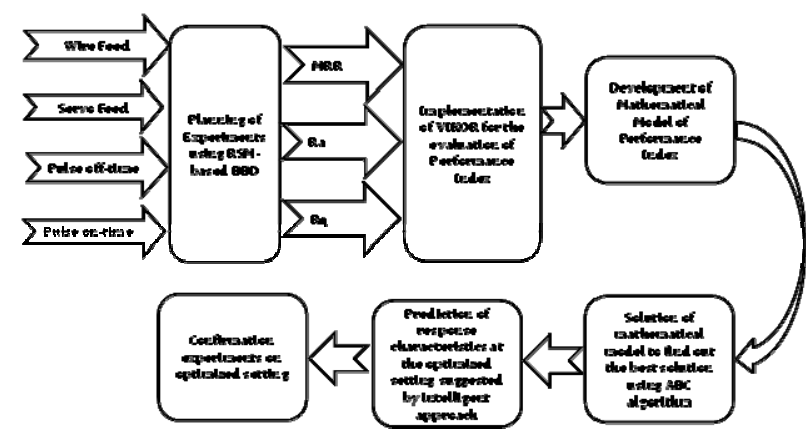

Figure 3. Methodology adopted in the present work

\subsection{Normalization by VIKOR}

The term VIKOR is evolved from Serbian word Vise Kriterijumska Optimizacija Kompromisno Resenje [24]. This is used to suggest a feasible solution where the process is measured by two or more than two response characteristics. It was developed in 1980 by Serafim Opricoveic to solve different problems associated with multiples responses. The problems are normally linked with conflicting in nature (combination of higher-thebetter and smaller-the-better).

In current work, the responses are a combination of attributes, which are varying in values also. Therefore, initially the values are normalized according to the standard method adopted [25]. After the identification of objectives, the decision matrix is developed as per equation (1).

$$
M=\left[\begin{array}{cccc}
M_{11} & M_{12} & \cdot & M_{1 n} \\
M_{21} & M_{22} & \cdot & M_{2 n} \\
\cdot & \cdot & \cdot & \cdot \\
M_{m 1} & M_{m 2} & \cdot & M_{m m}
\end{array}\right]
$$

where, $i=1,2, \ldots \ldots, m$ shows the input variables and $\mathrm{j}=1,2,3, \ldots, n$ signifies the response variables.
Table 1. Experimental matrix and results

\begin{tabular}{|c|c|c|c|c|c|c|c|}
\hline $\begin{array}{c}\text { Run } \\
\text { No }\end{array}$ & $\begin{array}{c}\mathbf{W F} \\
(\mathbf{m} / \mathbf{m i n})\end{array}$ & $\begin{array}{c}\mathbf{S V} \\
(\mathbf{V})\end{array}$ & $\begin{array}{c}\text { Poff } \\
(\boldsymbol{\mu s})\end{array}$ & $\begin{array}{c}\text { Pon } \\
(\boldsymbol{\mu s})\end{array}$ & $\begin{array}{c}\mathbf{M R R} \\
\left(\mathbf{m m}^{\mathbf{3}} \mathbf{m i n}\right)\end{array}$ & $\begin{array}{c}\text { Ra } \\
(\boldsymbol{\mu m})\end{array}$ & $\begin{array}{c}\mathbf{R q} \\
(\boldsymbol{\mu m})\end{array}$ \\
\hline 1 & 9 & 50 & 40 & 108 & 0.007 & 2.44 & 3.26 \\
\hline 2 & 6 & 50 & 20 & 112 & 0.038 & 3.85 & 4.67 \\
\hline 3 & 9 & 50 & 30 & 112 & 0.021 & 3.28 & 3.87 \\
\hline 4 & 9 & 65 & 40 & 112 & 0.036 & 3.73 & 4.54 \\
\hline 5 & 12 & 50 & 40 & 112 & 0.027 & 3.37 & 4.19 \\
\hline 6 & 12 & 50 & 30 & 108 & 0.009 & 2.37 & 3.24 \\
\hline 7 & 9 & 50 & 30 & 112 & 0.026 & 3.19 & 3.83 \\
\hline 8 & 12 & 50 & 30 & 116 & 0.044 & 4.41 & 5.28 \\
\hline 9 & 9 & 35 & 30 & 108 & 0.018 & 2.79 & 3.62 \\
\hline 10 & 9 & 65 & 30 & 116 & 0.044 & 4.48 & 5.33 \\
\hline 11 & 9 & 50 & 30 & 112 & 0.022 & 3.13 & 3.94 \\
\hline 12 & 6 & 50 & 30 & 116 & 0.041 & 4.23 & 5.12 \\
\hline 13 & 9 & 50 & 40 & 116 & 0.04 & 4.14 & 5.01 \\
\hline 14 & 9 & 35 & 30 & 116 & 0.045 & 4.51 & 5.32 \\
\hline 15 & 6 & 50 & 30 & 108 & 0.008 & 2.45 & 3.3 \\
\hline 16 & 9 & 50 & 30 & 112 & 0.023 & 3.22 & 3.85 \\
\hline 17 & 9 & 65 & 20 & 112 & 0.037 & 3.89 & 4.71 \\
\hline 18 & 6 & 35 & 30 & 112 & 0.03 & 3.57 & 4.49 \\
\hline 19 & 9 & 50 & 20 & 108 & 0.01 & 2.54 & 3.35 \\
\hline 20 & 9 & 35 & 40 & 112 & 0.037 & 3.79 & 4.58 \\
\hline 21 & 12 & 35 & 30 & 112 & 0.033 & 3.64 & 4.55 \\
\hline 22 & 12 & 65 & 30 & 112 & 0.029 & 3.49 & 4.39 \\
\hline 23 & 9 & 50 & 30 & 112 & 0.024 & 3.23 & 3.97 \\
\hline 24 & 9 & 35 & 20 & 112 & 0.039 & 3.92 & 4.74 \\
\hline 25 & 12 & 50 & 20 & 112 & 0.039 & 3.89 & 4.71 \\
\hline 26 & 6 & 65 & 30 & 112 & 0.029 & 3.43 & 4.32 \\
\hline 27 & 9 & 50 & 20 & 116 & 0.048 & 4.98 & 5.99 \\
\hline 28 & 9 & 65 & 30 & 108 & 0.01 & 2.57 & 3.41 \\
\hline 29 & 6 & 50 & 40 & 112 & 0.025 & 3.18 & 3.98 \\
\hline
\end{tabular}

After the development of decision matrix, the data normalization takes place according to the Equation 2 . All the data is converted into dimensionless number using ranking system and is depicted in Table 2. The performance index (PI) evaluated for all response characteristics is shown in Table 2.

$$
\bar{M}_{i j}=\frac{M_{i j}}{\sqrt{\sum_{i=1}^{n} M_{i j}^{2}}}
$$

\subsection{ABC Algorithm}

The ABC algorithm was suggested by karaboga in 2005 , which simulates the nature of bee colony [26]. it is used for the optimization in different problems of services and manufacturing. Three types of bees are used in the bee colony; onlooker bee, employee bee and scout bee. Onlooker bees watch the employee bee to check that the food source is worth anymore. Employee bees work to collect the food and store it at particular food source. The third type of bees (i.e. scout bees) looks after the new food source location.

The food source location is assumed as the solution of optimization problem in the search space. Initially, the number of bees available in the hive will be considered as the number of food source. The objective function on that position defines the quality of food source (fitness value). The smart nature of the bees is explained in the following steps:

-Bees start to explore the locations for good food source food in search space (fitness value).

- Once the food source is located, the bee become employee bee and starts to excerpt the food from the searched source. 
- The nectar extracted by the employee bee is uploaded in the hive by the employee bee after returning. After uploading the nectar, either she go back to the food source or share information about the food source location by performing dance.

- Once the food source became empty, the employee bee converted into scout bee for searching new food source location.

- The onlooker bees stay back in the hive to wait the employee bee. They check the quality of food source and select the best source providing maximum profit.

-The selection of the source is made according to its quality (fitness value). Primarily, three types of bees are described, however in actual there are two types of bees i.e. onlooker and employee types. The third type i.e. scout type is the exploratory nature of the employee bees and onlooker bees.

Table 2. data normalization and evaluation of pi

\begin{tabular}{|l|l|l|l|l|}
\hline $\begin{array}{l}\text { Sr. } \\
\text { No. }\end{array}$ & $\begin{array}{l}\text { Normalized } \\
\text { MRR }\end{array}$ & $\begin{array}{l}\text { Normalized } \\
\text { Ra }\end{array}$ & $\begin{array}{l}\text { Rqrmalized } \\
\text { Rq }\end{array}$ \\
\hline 1 & 0.0415 & 0.1269 & 0.1380 & 0.3064 \\
\hline 2 & 0.2253 & 0.2002 & 0.1977 & 0.6232 \\
\hline 3 & 0.1245 & 0.1706 & 0.1638 & 0.4589 \\
\hline 4 & 0.2134 & 0.1940 & 0.1922 & 0.5996 \\
\hline 5 & 0.1601 & 0.1753 & 0.1774 & 0.5127 \\
\hline 6 & 0.0534 & 0.1232 & 0.1372 & 0.3138 \\
\hline 7 & 0.1541 & 0.1659 & 0.1621 & 0.4822 \\
\hline 8 & 0.2609 & 0.2293 & 0.2235 & 0.7137 \\
\hline 9 & 0.1067 & 0.1451 & 0.1533 & 0.4051 \\
\hline 10 & 0.2609 & 0.2330 & 0.2257 & 0.7195 \\
\hline 11 & 0.1304 & 0.1628 & 0.1668 & 0.4600 \\
\hline 12 & 0.2431 & 0.2200 & 0.2168 & 0.6798 \\
\hline 13 & 0.2371 & 0.2153 & 0.2121 & 0.6645 \\
\hline 14 & 0.2668 & 0.2345 & 0.2252 & 0.7265 \\
\hline 15 & 0.0474 & 0.1274 & 0.1397 & 0.3145 \\
\hline 16 & 0.1364 & 0.1675 & 0.1630 & 0.4668 \\
\hline 17 & 0.2194 & 0.2023 & 0.1994 & 0.6211 \\
\hline 18 & 0.1779 & 0.1857 & 0.1901 & 0.5536 \\
\hline 19 & 0.0593 & 0.1321 & 0.1418 & 0.3332 \\
\hline 20 & 0.2194 & 0.1971 & 0.1939 & 0.6103 \\
\hline 21 & 0.1956 & 0.1893 & 0.1926 & 0.5776 \\
\hline 22 & 0.1719 & 0.1815 & 0.1859 & 0.5393 \\
\hline 23 & 0.1423 & 0.1680 & 0.1681 & 0.4783 \\
\hline 24 & 0.2312 & 0.2039 & 0.2007 & 0.6357 \\
\hline 25 & 0.2312 & 0.2023 & 0.1994 & 0.6329 \\
\hline 26 & 0.1719 & 0.1784 & 0.1829 & 0.5332 \\
\hline 27 & 0.2846 & 0.2590 & 0.2536 & 0.7971 \\
\hline 28 & 0.0593 & 0.1336 & 0.1444 & 0.3373 \\
\hline 29 & 0.1482 & 0.1654 & 0.1685 & 0.4821 \\
\hline & & & & \\
\hline
\end{tabular}

The present research problem of optimization is the constrained type optimization problem. Thus, handling method proposed by Deb [27] is used for the optimization. The main reason for this selection is the three simple and basic heuristic rules. In Deb's method, the two solution are always compared at a time and having tournament selection operators. The three heuristic rules are as: (i) the feasible solution is always given more importance rather than infeasible solution, (ii) if two feasible solutions appeared, then importance is given to that solution which have better objective function value, (iii) The one having minimum constraint violation is selected from two infeasible solutions.

The analysis of data by $\mathrm{ABC}$ is fast due to nonrequirement of feasible solution. It can be operated on any population and directs towards the feasible region. The initialization by the feasible solutions is timeconsuming. ABC algorithm eliminates this and saves a lot of time. Scout production algorithm suggests a mechanism which allows the infeasible solutions in the population. The food location can be investigated by $\mathrm{ABC}$ algorithm using the following Equation (3).

$$
Y_{j}=\left\{\begin{array}{l}
x_{i j}+\phi_{i j}\left(x_{i j}-x_{k j}\right), \text { if } R_{j}<M R \\
x_{i i}, \text { otherwise }
\end{array}\right.
$$

where $\mathrm{k} \in\{1,2,3 \ldots, \mathrm{SN}\}$ is an alternately select index. $\mathrm{K}$ should be different from ' $\mathrm{i}$ ' and determined randomly. The range of $\mathrm{Rj}$ is $[0,1]$ and is a real number. However, $\mathrm{j} \in\{1,2, \ldots, \mathrm{D}\}$. M-modification rate. The scouts are produced according to predetermined period. This period is terms as a control variable for scout production period (SPP) of the algorithm. The pseudocode for the $\mathrm{ABC}$ algorithm is provided in appendix. The mathematical model developed after the analysis of performance index evaluated in Table 3 is given in equation (4).

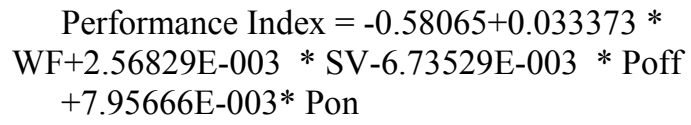

The range selected for the optimization of PI is given in Equations 5-8. This range is termed as the search space of food location. Equation 4 is the fitness function which is to be optimized.

$$
\begin{aligned}
& 6 \leq \mathrm{WF} \leq 12 \\
& 35 \leq \mathrm{SV} \leq 65 \\
& 20 \leq \mathrm{Poff} \leq 40 \\
& 108 \leq \text { Pon } \leq 116
\end{aligned}
$$

It is presented in Fig. 4 that with the increase in number of iterations the PI value increases from 0.65 to 0.775 at 17 th iteration. After that its value remains constant at 0.775 till the number of iterations remains constant. The time taken by $\mathrm{ABC}$ algorithm is very small ( $4 \mathrm{~s})$ to get the optimized value of PI. The position of food source i.e. the setting of process variable at which best value of PI is obtained as WF: 12m/min; SV: 65V; Poff: $20 \mu \mathrm{s}$; Pon: $116 \mu \mathrm{s}$. 


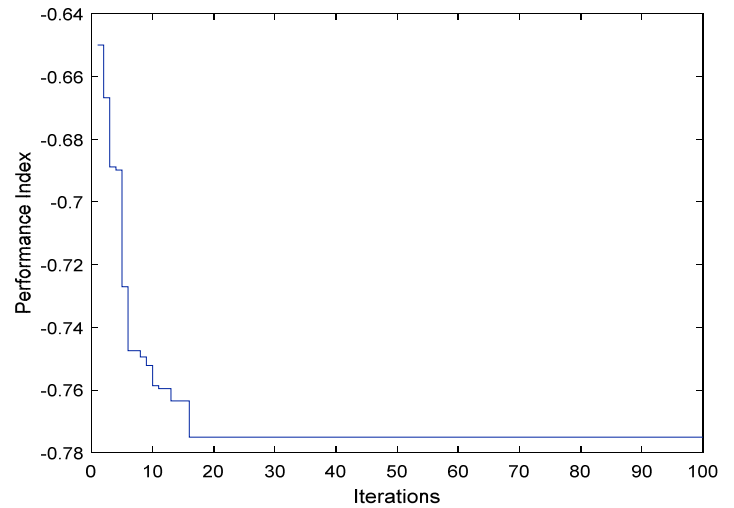

Figure 4. Evaluation of performance index with the number of iterations

\subsection{Influence of Process Parameters}

It is evident from Fig. 5 that increasing WF and Pon increase MRR, however it is found to be decreased with SV and Poff. The maximum MRR is obtained at high WF $(12 \mathrm{~m} / \mathrm{min})$, low SV $(35 \mathrm{~V})$, low Poff $(20 \mu \mathrm{s})$ and high Pon $(116 \mu \mathrm{s})$. Pooled ANOVA for MRR is given in Table 3 .

The model is found significant and lack of fit is nonsignificant, which proves the statistical accuracy of the result data. The WF and SV are forcefully incorporated in the model to make it hierarchical. The P-value for WF and SV are greater than 0.05 , still these terms are considered in the model. This happens due to the quadratic terms of the WF and SV. The P-value of the quadratic terms of WF and SV are less than 0.05, which makes these terms an integral part of model.

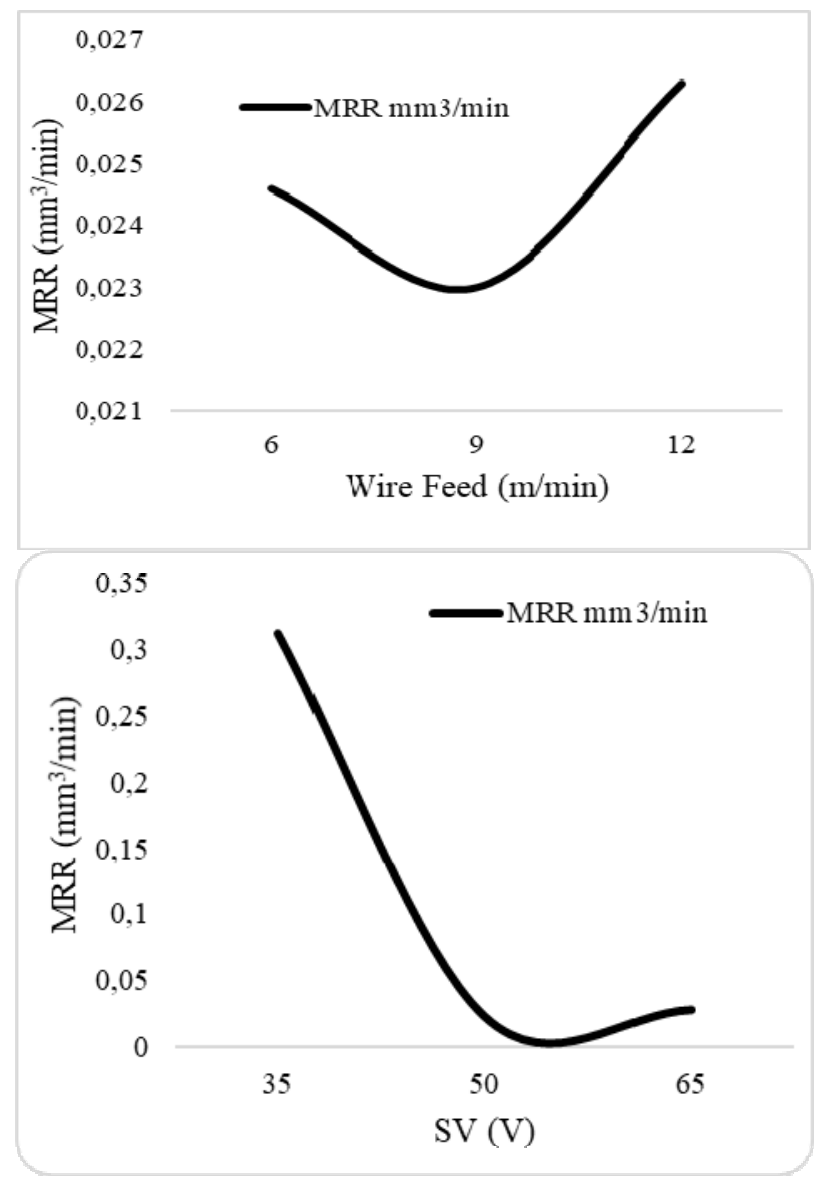

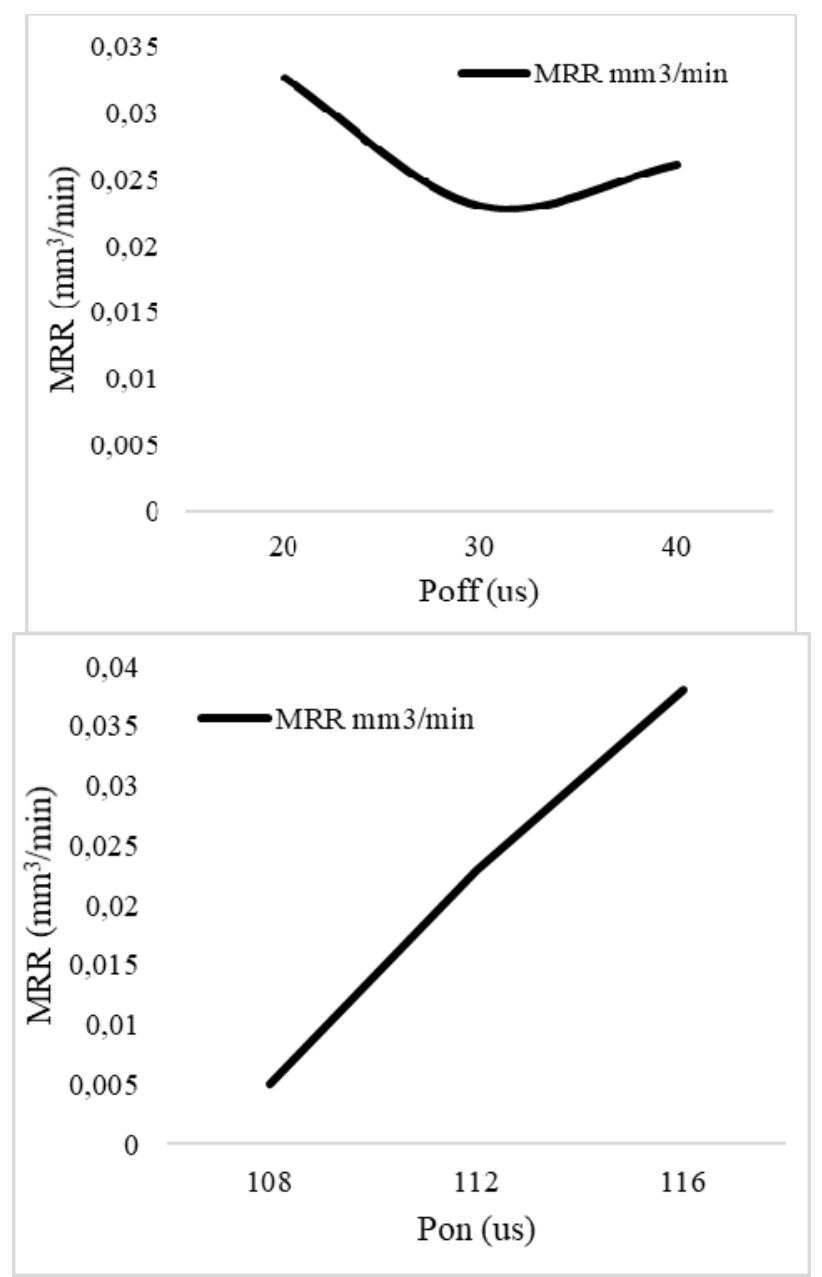

Figure 5. Variation of MRR with variable process parameters

Fig. 6 shows that the minimum $\mathrm{Ra}$ is obtained at low WF $(6 \mathrm{~m} / \mathrm{min})$, medium SV (50 v), medium Poff $(30 \mu \mathrm{s})$ and low Pon $(108 \mu \mathrm{s})$. Ra depends upon the crater size eroded from the work surface. The crater size varies as per the amount of energy (discharge) in the spark gap. At high discharge energy parameters (high WF, low SV, low Poff and high Pon), the crater size is large which increases the $\mathrm{Ra}$ value. The pooled ANOVA for $\mathrm{Ra}$ is given in Table 4, which represent signs of good ANOVA by the values of model and lack of fit. The model became hierarchical after the insertion of SV. Pon has maximum contribution to the $\mathrm{Ra}$ value due to maximum SS value and F-value. From the statistical analysis, it has been found that the interaction term of Poff and Pon, quadratic terms of SV and Poff play a crucial role in the modeling of $\mathrm{Ra}$. The trends of variation of $\mathrm{Rq}$ were also found almost similar to $\mathrm{Ra}$. It is worth mentioning that the medium WF $(9 \mathrm{~m} / \mathrm{min})$, medium SV $(50 \mathrm{v})$, medium Poff $(30 \mu \mathrm{s})$ and low Pon $(108 \mu \mathrm{s})$ produce the minimum $\mathrm{Rq}$ value. The pooled ANOVA for $\mathrm{Rq}$ is given in Table 5 and presents a significant model and nonsignificant lack-of-fit. The statistical summary shows that the Poff, Pon, interaction term of Poff and Pon, quadratic term of WF, SV, Poff and Pon play very influential role in the analysis of Rq. The term WF and SV have greater P-values, still these terms are considered in the model. This is due to the quadratic terms of these factors. Thus, to make hierarchy, these factors are considered in the model. 


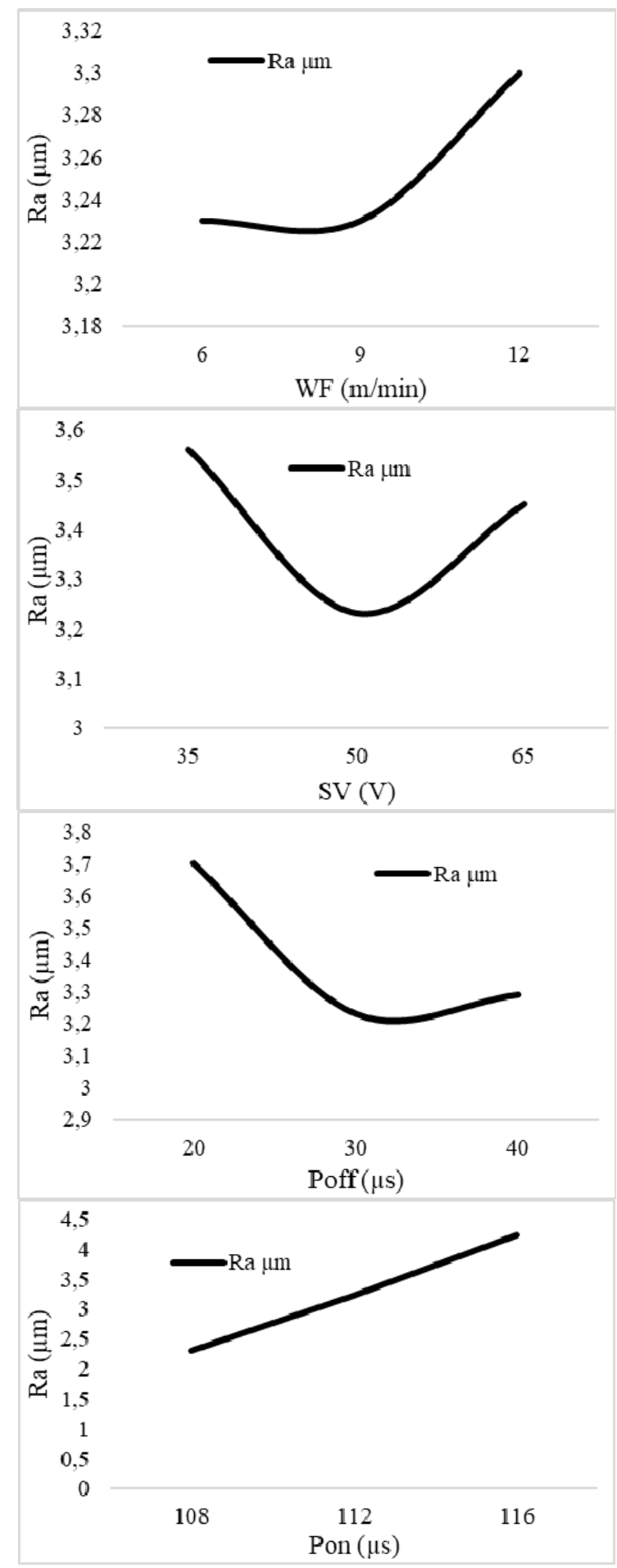

Figure 6. Variation of Ra with variable process parameters

Table 3. Pooled anova for MRR

\begin{tabular}{|l|c|c|c|c|c|c|}
\hline Source & SS & df & MS & F-Value & P-value & \\
\hline Model & $4.01 \mathrm{E}-03$ & 7 & $5.73 \mathrm{E}-04$ & 70.5 & $<0.0001$ & significant \\
\hline WF & $8.33 \mathrm{E}-06$ & 1 & $8.33 \mathrm{E}-06$ & 1.03 & 0.3226 & \\
\hline SV & $2.41 \mathrm{E}-05$ & 1 & $2.41 \mathrm{E}-05$ & 2.97 & 0.0997 & \\
\hline Poff & $1.27 \mathrm{E}-04$ & 1 & $1.27 \mathrm{E}-04$ & 15.61 & 0.0007 & \\
\hline Pon & $3.33 \mathrm{E}-03$ & 1 & $3.33 \mathrm{E}-03$ & 410.48 & $<0.0001$ & \\
\hline $\mathbf{W F}^{2}$ & $4.23 \mathrm{E}-05$ & 1 & $4.23 \mathrm{E}-05$ & 5.21 & 0.0331 & \\
\hline SV $^{2}$ & $3.19 \mathrm{E}-04$ & 1 & $3.19 \mathrm{E}-04$ & 39.23 & $<0.0001$ & \\
\hline Poff $^{2}$ & $2.74 \mathrm{E}-04$ & 1 & $2.74 \mathrm{E}-04$ & 33.74 & $<0.0001$ & \\
\hline Residual & $1.71 \mathrm{E}-04$ & 21 & $8.12 \mathrm{E}-06$ & & & \\
\hline Lack of Fit & $1.56 \mathrm{E}-04$ & 17 & $9.16 \mathrm{E}-06$ & 2.48 & 0.1968 & $\begin{array}{c}\text { not } \\
\text { significant }\end{array}$ \\
\hline $\begin{array}{l}\text { Pure } \\
\text { Error }\end{array}$ & $1.48 \mathrm{E}-05$ & 4 & $3.70 \mathrm{E}-06$ & & & \\
\hline Cor Total & $4.18 \mathrm{E}-03$ & 28 & & & & \\
\hline
\end{tabular}

Table 4. Pooled anova for Ra

\begin{tabular}{|c|c|c|c|c|c|c|}
\hline Source & SS & df & MS & F-Value & P-value & \\
\hline Model & 12.78 & 6 & 2.13 & 170.63 & $<0.0001$ & significant \\
\hline SV & 0.033 & 1 & 0.033 & 2.65 & 0.1178 & \\
\hline Poff & 0.49 & 1 & 0.49 & \begin{tabular}{|l|}
39.09 \\
\end{tabular} & $<0.0001$ & \\
\hline Pon & 11.19 & 1 & 11.19 & \begin{tabular}{|l|}
896.67 \\
\end{tabular} & $<0.0001$ & \\
\hline Poff*Pon & 0.14 & 1 & 0.14 & \begin{tabular}{|l|l|}
10.97 \\
\end{tabular} & \begin{tabular}{|l|}
0.0032 \\
\end{tabular} & \\
\hline $\mathbf{S V}^{2}$ & 0.55 & 1 & 0.55 & 44.01 & $<0.0001$ & \\
\hline Poff $^{2}$ & 0.51 & 1 & 0.51 & 40.57 & $<0.0001$ & \\
\hline Residual & 0.27 & 22 & 0.012 & & & \\
\hline $\begin{array}{c}\text { Lack of } \\
\text { Fit }\end{array}$ & 0.26 & 18 & 0.015 & 4.78 & 0.07 & $\begin{array}{c}\text { not } \\
\text { significant }\end{array}$ \\
\hline Pure Error & 0.012 & 4 & $3.05 \mathrm{E}-03$ & & & \\
\hline Cor Total & 13.06 & 28 & & & & \\
\hline
\end{tabular}

\section{Table 5. Pooled anova for Rq}

\begin{tabular}{|l|l|l|l|l|l|l|}
\hline Source & SS & df & MS & F-Value & P-value & \\
\hline Model & 14.05 & 9 & 1.56 & 117.76 & $<0.0001$ & significant \\
\hline WF & 0.019 & 1 & 0.019 & 1.45 & 0.2436 & \\
\hline SV & 0.03 & 1 & 0.03 & 2.26 & 0.1489 & \\
\hline Poff & 0.57 & 1 & 0.57 & 42.82 & $<0.0001$ & \\
\hline Pon & 11.74 & 1 & 11.74 & 885.69 & $<0.0001$ & \\
\hline $\begin{array}{l}\text { Poff } \\
\text { *Pon }\end{array}$ & 0.2 & 1 & 0.2 & 14.94 & 0.001 & \\
\hline WF $^{2}$ & 0.17 & 1 & 0.17 & 13.03 & 0.0019 & \\
\hline SV $^{2}$ & 0.95 & 1 & 0.95 & 71.84 & $<0.0001$ & \\
\hline Poff $^{2}$ & 0.79 & 1 & 0.79 & 59.74 & $<0.0001$ & \\
\hline Pon $^{2}$ & 0.17 & 1 & 0.17 & 12.83 & 0.002 & \\
\hline Residual & 0.25 & 19 & 0.013 & & & \\
\hline $\begin{array}{l}\text { Lack of } \\
\text { Fit }\end{array}$ & 0.24 & 15 & 0.016 & 4.37 & 0.082 & $\begin{array}{l}\text { not } \\
\text { significant }\end{array}$ \\
\hline $\begin{array}{l}\text { Pure } \\
\text { Error }\end{array}$ & 0.014 & 4 & $\begin{array}{l}3.62 \\
\text { E-03 }\end{array}$ & & & \\
\hline $\begin{array}{l}\text { Cor } \\
\text { Total }\end{array}$ & 14.3 & 28 & & & & \\
\hline
\end{tabular}

\section{VALIDATION}

After obtaining the optimal parameter combination using hybrid RSM-VIKOR-ABC approach, the confirmation experiments were conducted (at WF: $12 \mathrm{~m} / \mathrm{min}$; SV: 65V; Poff: $20 \mu \mathrm{s}$; Pon: $116 \mu \mathrm{s})$ to check the efficacy of proposed approach. The improvement in the experimental results and the closest pi values results (MRR setting is selected due to maximum PI out of MRR, Ra and Rq) are also shown in Table 6. It is also analyzed that the predicted values have a close agreement with the experimental values. an ameli-oration of $11.51 \%, 1.67 \%, 15.96 \%$ and $14.54 \%$ was obtained in PI, MRR, Ra and Rq respectively using the proposed approach of the optimization. Thus, the proposed approach of optimization can be effectively used to optimize the process variable for the WEDM of WC-Co composite.

Table 6. Confirmation experiments at the optimal setting suggested by RSM-VIKOR-ABC

\begin{tabular}{|c|c|c|c|c|c|c|}
\hline \multirow[t]{2}{*}{$\begin{array}{l}0 \\
0 \\
0 \\
00 \\
0 \\
\simeq\end{array}$} & 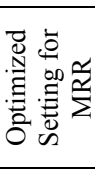 & 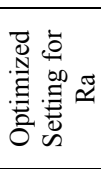 & 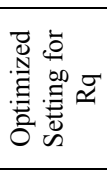 & \multicolumn{2}{|c|}{$\begin{array}{c}\text { Optimized } \\
\text { Setting by Hybrid } \\
\text { approach } \\
(\mathrm{WF})_{3}(\mathrm{SV})_{3} \\
(\mathrm{Poff})_{1}(\mathrm{Pon})_{3}\end{array}$} & \multirow{2}{*}{ 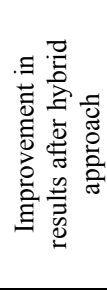 } \\
\hline & $\begin{array}{l}(\mathrm{WF})_{3} \\
(\mathrm{SV})_{1} \\
(\mathrm{Poff})_{1} \\
(\mathrm{Pon})_{3} \\
\end{array}$ & $\begin{array}{l}(\mathrm{WF})_{1} \\
(\mathrm{SV})_{2} \\
(\mathrm{Poff})_{2} \\
(\mathrm{Pon})_{1} \\
\end{array}$ & $\begin{array}{l}(\mathrm{WF})_{2} \\
(\mathrm{SV})_{2} \\
(\mathrm{Poff})_{2} \\
(\mathrm{Pon})_{1} \\
\end{array}$ & $\begin{array}{l}\text { Predicted } \\
\text { Results }\end{array}$ & $\begin{array}{l}\text { Confir } \\
\text { mation } \\
\text { results }\end{array}$ & \\
\hline PI & 0.695 & 0.608 & 0.508 & 0.775 & - & $11.51 \%$ \\
\hline $\begin{array}{c}\text { MR } \\
\text { R }\end{array}$ & 0.06 & 0.007 & 0.006 & 0.057 & 0.061 & $1.67 \%$ \\
\hline $\mathrm{Ra}$ & 5.23 & 2.31 & 2.31 & 4.47 & 4.51 & $15.96 \%$ \\
\hline $\mathrm{Rq}$ & 6.46 & 3.19 & 3.06 & 5.59 & 5.64 & $14.54 \%$ \\
\hline
\end{tabular}




\section{CONCLUSIONS}

In the present work, WC-Co composite type DTM material has been successfully cut by WEDM at optimum process parameters obtained by hybrid RSMVIKOR-ABC technique. The following conclusions can be drawn from this research:

1. The WC-Co composite can be successfully machined by WEDM and the proposed approach predict results with $\pm 5 \%$.

2. The optimal setting of WEDM for machining of WC-Co, as obtained by RSM-VIKOR-ABC is WF: 12 m/min; SV: 65V; Poff: $20 \mu$ s and Pon: $116 \mu \mathrm{s}$.

3. This novel hybrid intelligent optimization technique successfully enhanced wire-EDM produc-tivity and surface quality of WC-Co composites. The results for multiperformance optimization are: Ra- $4.51 \mu \mathrm{m}, \mathrm{Rq}-$ $5.64 \mu \mathrm{m}$, MRR $-0.061 \mathrm{~mm}^{3} / \mathrm{min}$.

4. ANOVA of the MRR, $\mathrm{Ra}$ and $\mathrm{Rq}$ indicated that the pulse off-time and pulse on-time are the most contributing factors in the WEDM of WC-Co composite.

5. An improvement in the response characteristics is obtained while conducting the validation experiments at the optimum process parameter setting. An improvement of $11.51 \%, 1.67 \%, 15.96 \%$ and $14.54 \%$ is obtained in PI, MRR, $\mathrm{Ra}$ and $\mathrm{Rq}$ respectively.

6 . Whether to obtain best surface quality or process productivity, or both simultaneously, optimum settings of wire-EDM parameters obtained in the present work can be readily used for machining of WC-Co compo-sites.

The hybrid intelligent approach can also be used for the prediction and optimization of other WEDM response characteristics or machinability indicators, namely, corner deviation, residual stresses, recast layer thickness, dimensional accuracy etc. It can also be tried for machinability enhancement of other DTM materials in case of various other advanced machining processes.

\section{APPENDIX}

Pseudo-code for ABC algorithm used in present research is provided below:

1. Initialize the solutions $(\mathrm{xi}, \mathrm{j})$ for the populations, where, $i=1 \ldots . . S N, j=1, \ldots \ldots, D$

2. Investigate the population

3. $\mathrm{Cycle}=1$

4. Repeat

5. Find out the new solutions (vi,j) for the employed bees

6. Selection process be applied according to Deb's method

7. Evaluate Pi,j (i.e. probability value) for $x i, j$.

8. Find out the new solutions $(v i, j)$ for the onlooker

bees using solution $(\mathrm{xi}, \mathrm{j})$ and probability $\mathrm{Pi}, \mathrm{j}$.

9. Repeat step 6

10. Investigate the unrestricted solutions for scout (if available) and replace them with new random solution

11. Remember the best solution attained till now

12. $\mathrm{Cycle}=$ cycle +1

13. until cycle $=\mathrm{MCN}$

\section{REFERENCES}

[1] Mehrotra, P.K., Johnson, J.L., Wolfe, T.A..: Production of Carbide Powders, in: Samal, P.,
Newkirk, J. (eds) ASM Handbook Powder Metallurgy, 2015.

[2] Kim, H.C., Shon, I.J., Munir, Z.A.: Rapid sintering of ultra-fine WC- $10 \%$ Co by high-frequency induction heating, J. Mater. Sci, Vol. 40, No. 11, pp. 2849-2854, 2005.

[3] Jahan, M.P., Rahman, M., Wong, Y.S.: A review on the conventional and micro-electro discharge machining of tungsten carbide, Int. J. Mach. Tool Manuf, Vol. 51, No. 12, pp. 837-858, 2011.

[4] Liu, K., Li, X.P.: Ductile cutting of tungsten carbide, J. Mater. Process Technol, Vol. 113, No. 1-3, pp. 348-354, 2001.

[5] Liu, K., Li, X.P., Rahman, M.: Characteristics of high-speed micro cutting of tungsten carbide, J. Mater. Process Technol, Vol. 140, No. 1-3, pp. 352-357, 2003.

[6] Engqvist, H., Ederyd, S., Axen, N., Hogmark, S.: Grooving wear of single-crystal tungsten carbide, Wear, Vol. 230, No. (2), pp. 165-174, 1999.

[7] Jia, K., Fischer, T.E.: Sliding wear of conventional and nanostructured cemented carbides, Wear, Vol. 203-204, pp. 310-318, 1997.

[8] Kondaya, D., Krishna, A.G.: An integrated evolutionary approach for modelling and optimization of wire electrical discharge machining, Proc. IMechE. Part B, J. Eng. Manuf., Vol. 225, pp. 549-567, 2011.

[9] Ghadai, R.K., Kalita, K., Gao, X.Z.: Symbolic Regression Metamodel Based Multi-Response Optimization of EDM Process, FME Transactions, Vol. 48, pp. 404-410, 2020.

[10]Lee, S.H., Li, X.P.: Study of the surface integrity of the machined workpiece in the EDM of tungsten carbide, J. Mater. Process Technol, Vol 139, No. 13, pp. 315-321, 2003.

[11] Naveed, R., Mufti, N.A., Mughal, M.P. et al.: Machining of curved profiles on tungsten carbidecobalt composite using wire electric discharge process. Int J Adv Manuf Technol, Vol. 93, pp. 1367-1378, 2017.

[12] Mahdavinejad, R.A., Mahdavinejad, A.: ED machining of WC-Co, J. Mater. Process Technol, Vol. 162, No. 163, pp. 637-643, 2005.

[13]Kim, C.H., Kruth, J.P.: Influence of electrical conductivity of dielectrical fluid on WEDM of sintered carbide, KSME Int. J, Vol. 15, No. 12, pp. 1276-1282, 2001.

[14] Lauwers, B., Liu, W., Eeraerts, W.: Influence of the composition of WC-based cermets on manufacturability by wire-EDM, J. Manuf. Process, Vol. 8, No. 2, pp. 83-89, 2006.

[15] Marichamy, S., Ravichandran, M., Stalin, B., Babu, B.S.: Optimization of Abrasive Water Jet Machining Parameters for $\alpha-\beta$ brass using Taguchi Methodology, FME Transactions, Vol. 47, pp. 116121, 2019.

[16] Gautam, G.D., Mishra, D.R.: Multiple Kerf Quality Optimization in Laser Cutting of BFRP Composite 
using Grey Relational based Genetic Algorithm, FME Transactions, Vol. 48, pp. 636-650, 2020.

[17] Singh, R.K., Gangwar, S., Singh, D.K.: Exploration of GRA Based Multiobjective Optimization of Magnetic Abrasive Finishing Process using Simulated Annealing, FME Transactions, Vol. 48, pp. 195-203, 2020.

[18] Majumder, H., Maity, K.: Prediction and optimization of surface roughness and microhardness using grnn and MOORA-fuzzy-a MCDM approach for nitinol in WEDM, Meas, Vol. 118, pp. 1-13, 2018.

[19] Tzeng, C.Z., Yang, Y.K., Hsieh, M.H., Jeng, M.C.: Optimization of wire electrical discharge machining of pure tungsten using neural network and response surface methodology, Proceedings of the Institution of Mechanical Engineers, Part B: Journal of Engineering Manufacture, Vol. 225, No. 6, pp. 841$852,2011$.

[20]Mukherjee, R., Chakraborty, S., Samanta, S.: Selection of wire electrical discharge machining process parameters using non-traditional optimization algorithms, Applied Soft Computing, Vol. 12, pp. 2506-2516, 2012.

[21] Nadda, R., Kumar, R., Singh, T., Chauhan, R., Patnaik, A., Gangil, B.: Experimental investigation and optimization of cobalt bonded tungsten carbide composite by hybrid AHP-TOPSIS approach, Alexandria Engineering Journal, Vol. 57, pp. 34193428, 2018.

[22] EI-Bahloul, S.A.: Optimization of wire electrical discharge machining using statistical methods coupled with artificial intelligence techniques and soft computing, SN Appl Sci, Vol. 2, Article No. 49, 2020.

[23] Montgomery, D.G.: Design and analysis of experiments, John Willey \& Sons, New Delhi, 2009.

[24] Opricovic, S., Tzeng, G.H.: Compromise solution by MCDM methods: a comparative analysis of VIKOR and TOPSIS, Eur. J. Oper. Res, Vol. 156, pp. 445-455, 2004.
[25]Khan, A., Maity, K.: A novel MCDM approach for simultaneous optimization of some correlated machining parameters in turning of CP-titanium grade 2, J. Eng. Res. Afr, Vol. 22, Article No. 94, 2016.

[26]Zhu, G., Kwong, S.: Gbest-guided artificial bee colony algorithm for numerical function optimization, App. Math Comp, Vol. 217, No. 7, pp. 3166-3173, 2010.

[27]Deb, K.: An introduction to Genetic Algorithms, Sadhana, Vol. 24, pp. 293-315, 1999.

\section{ИНТЕЛИГЕНТНА ОПТИМИЗАЦИЈА ЕDМ \\ ПАРАМЕТАРА ПОВРШИНСКЕ ХРАПАВОСТИ \\ И БРЗИНЕ УКЛАҢАЊА МАТЕРИЈАЛА ПРИ МАШИНСКОЈ ОБРАДИ ШС-СО КОМПОЗИТА}

\section{К. Гупта}

Приказана је обрада WC-Со композита електричним пражњењем (EDM) и оптимизација параметара процеса применом интегрисаних техника RSM, VIKOR и ABC алгоритма да би се добио најбољи скуп индикатора обрадљивости. Размотрени су променљиви параметри процеса WF, SV, Pon и Poff, као и индикатори обрадљивости Rq, Ra и MRR. Из-ведено је укупно 29 експеримената базираних на BBD техници методологије одзива површине. VIKOR je коришћен за нормализовање одзива док је решавање емпиријских модела обављено помоћу АВС алгоритма у циљу добијања скупа оптими-зо-ваних параметара процеса. Оптимални EDM пара-метри су

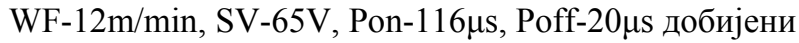
интелигентном RSM-VIKOR-ABC техни-ком која је дала истовремено најбоље резултате Ra-451 $\mu \mathrm{m}$, Rq$5,64 \mu \mathrm{m}$, MRR- $0,061 \mathrm{~mm}^{3} / \mathrm{min}$. Тест вали-дације je потврдио побољшање од $15 \%$ карак-те-ристика одзива чиме је доказана ефикасност нове хибридне технике оптимизације. Оптимални пара-метри се могу одмах користити у индустрији за добијање најбољег квалитета површине и продук-тивности код обраде WC-Cо композита EDM методом. 